\title{
Trauma Experience, Identity, and Narratives
}

\author{
Aloysius Soesilo \\ Fakultas Psikologi Universitas Kristen Satya Wacana, Salatiga
}

\begin{abstract}
Abstrak
Peristiwa kekerasan dan mengerikan seperti konflik berdarah dan pembunuhan merupakan suatu realitas yang meninggalkan dampak permanen pada korban. Individu yang mengalami trauma akan terus menerus bergumul dengan makna kejadian yang telah dialami bahkan sesudah peristiwa trauma itu sendiri berlalu. Elemen kritikal bagi individu yang mengalami trauma adalah asesmen subyektif mengenai bagaimana mereka merasa terancam dan tak berdaya. Studi tentang trauma sosial-psikologi menghadapkan kita pada kondisi mengenai kodrat manusia baik dari sisi terbaik maupun terburuk.Makalah ini dimulai dengan bahasan mengenai apa yang menjadikan trauma dan bagaimana trauma berpengaruh atas hidup individu yang mengalaminya. Sebagai fenomen yang berkaitan erat dengan stres, maka akan bermanfaat bila dampak trauma dipertimbangkan dari aspek diri (self), yang mana konsep self ini sendiri merupakan seperangkat faktor yang kompleks. Trauma akan menggoyangkan dan bahkan mengubah komponen struktural dan fungsional dari self. Dihadapkan dengan pengalaman trauma, individu harus memobilisasikan segenap sumbersumber yang ada dalam diri maupun dalam lingkungannya sebagai jalan koping dengan situasi hidupnya. Pembahasan tentang koping akan mencakup konseptualisasi yang lebih luas daripada apa yang telah diusulkan oleh Lazarus. Perspektif yang lebih luas ini lebih bermanfaat bagi kita khususnya bila kita mempelajari naratif sebagai upaya oleh individu untuk memahami dan memaknai apa yang telah menimpa diri mereka. Setiap orang memiliki motif untuk menemukan makna, nilai-nilai (values) dan tujuan hidup, khususnya setelah mereka mengalami peristiwa yang mengancam kehidupan mereka, semua aspek ini muncul dalam naratif.
\end{abstract}

Kata kunci: trauma, identity, self, coping, stress, narrative

\section{Introduction}

Malicious and dreadful events such as horrors and atrocities have become a reality that many people have to deal with. The scars of trauma have left a permanent impact to some victimized people. Victims attach to these events as fundamental as the trauma itself. Traumatized people's interpretations of the meaning of the event continue to evolve well after the trauma itself has passed. Unlike other forms of psychological disorders, the core issue in

\footnotetext{
${ }^{1}$ Korespondensi mengenai isi artikel ini dapat melalui: alsoes99@yahoo.com
}

trauma is reality. "It is indeed the truth of the trauma experience that forms the center of its psychopathology; it is not a pathology of falsehood or displacement of meaning, but of history itself" (Caruth, 1995, p. 5). However, the critical element that makes an event traumatic is the subjective assessment by victims of how threatened and helpless they feel. The study of trauma confronts one with the best and the worst in human nature, and is bound to provoke a range of intense personal reactions in the people involved (van der Kolk, 1996). 
The discussion will begin with the notion of what constitutes trauma and how trauma affects the individual. As a stress-related phenomenon, it is useful to consider trauma impacts to the self as a complex set of factors that alter the structural and functional components of the self. Confronted with a threat, the individual has to mobilize their resources as a way of coping with the situation. Our discussion of coping will cover a much broader conceptualization than what has been proposed by Lazarus. This broader conceptualization of coping strategy is more beneficial for us especially when we study narrative as a way of people's attempt to make sense and meaning of what has happened to them. This is a core motive in every human being to find meaning, values, and purposes in their lives, especially after a life-threatening experience.

\section{The tyranny of the past}

Confronted with daily life challenges, human being have the capacity to survive and adapt. However, in more severe stressful challenges, we have to mobilize all of our resources and these resources can be depleted as a consequences of prolonged and persistent pressures. Many studies that would be reviewed here have shown that traumatic experiences can alter people's psychological, social, and biological allostatis or equilibrium. As a result of this, people with a traumatic experience may concentrate selectively on particular reminders of their past and these reminders come to taint all other contemporary experiences. This "tyranny of the past" interferes with the victims' ability to pay attention to both new and familiar situations (van der Kolk, 1996).

How are traumatic stressors different from ordinary ones? What make a stressor "traumatic"? A stressor could be perceived as a threat to the psychological and/or physical integrity. To define trauma, in Green's (1999) view, there are three variables that we have to consider: an objectively defined event, the person's interpretation of its meaning, and the person's emotional reaction to it. A stress response occurs when novelty, unpredictability, a decreased sense of control, and a threat to the ego is perceived in the situation (Marin \& Lupien, 2011). Consequently, a stressor is relative and its determinants inducing the response may differ for different people. This fact underlines the notion of individual differences that has to be taken into consideration in the study of stress in general and trauma in particular. Many factors contribute to individual differences in interpretation of and response to threat.

DSM-IV defines the traumatic stressor as when a person "experienced, witnessed, or was confronted with an event or events that involved actual or threatened death or serious injury, or a threat to the physical integrity of self or others" and had a subjective response of "intense fear, helplessness, or horror" (American Psychiatric Association, 2000, p. 467).

The diagnostic criteria include three main categories (1) the traumatic event is persistently reexperienced; (2) persistent avoidance of stimuli associated with the trauma and numbing of general responsiveness; and (3) persistent symptoms of increased arousal (American Psychiatric Association, 2000, pp. 467-468).

Most people who have been exposed to traumatic stressors are somehow able to go on with their lives without becoming haunted by the memories of what has happened to them. However, that does not mean the trauma events go unnoticed. 
After exposure to a trauma, some people become preoccupied with the event. They experience involuntary intrusive memories as a way of responding to dreadful experiences. They are unable to integrate these experiences and start developing a variety of symptoms such as avoidance and hyperarousal (Van der Kolk (1996) has pointed out that "it is the persistence of intrusive and distressing recollections, and not the direct experience of the trauma event itself, that actually drives the biological and psychological dimensions of PTSD" (p. 5).

\section{Trauma and Loss}

Violent communal conflicts and killings result in trauma-related loss. Loss of this kind can be conceptualized as a trauma stressor that can lead to traumatic stress. Therefore, there is a great deal of intersection between trauma loss and trauma stress, both in event dimensions and psychological outcome (Neria \& Litz, 2004). In trauma loss, a person is forcefully separated from his or her family member or close friends by death or other reasons. The study of separation loss has been pioneered by John Bowlby (1969). Trauma loss often results in unresolved and complicated reactions to loss, leading to chronic, unresolved grief reactions (Neria \& LItz, 2004).

The loss of a child, spouse, sibling, parent, close friend, colleague, or acquaintance each holds a different meaning for an individual in terms of the relationship that is lost. Violent and unexpected loss leads to severe feelings of personal vulnerability, creating intense anxiety (Stroebe \& Schut, 1999). Green (2000) points out that loss by traumatic means should be treated as a stressor and that the most stigmatized deaths tended to produce higher rates of stress disorder. This type of stressor led to more severe intrusive symptoms and greater functional impairment. These findings suggest that loss by traumatic means may be more pernicious than direct trauma.

On account of the complexity of response to loss by trauma, Neria \& Litz (2004) have argued that symptoms of PTSD fail to sufficiently capture the unique experiences of those victims who suffer from chronic grief as result of violent loss of an important attachment figure. According to these two authors, a distinction should be made between interpersonal or social trauma (for example, sexual or physical assault by caregivers and attachment figures) and non-interpersonal trauma (for example, motor vehicle accident). Thus, traumatic experiences have a different psychological impact depending on the meaning attributed to the event. The psychological impact of loss by trauma means is mediated by how the person construes the implications of the events for his or her life.

Prigerson and colleagues (quoted in Neria \& Litz, 2004) have proposed the diagnostic criteria for traumatic grief. These criteria include two components: the separation distress of losing an attachment figure and the traumatic distress of adjusting to life without that figure. In addition to grief symptoms such as loneliness and yearning for the lost person, posttraumatic stress symptoms (for example, intrusive memories) are included as well.

The symptoms of separation distress are (a) intrusive, distressing preoccupation with the deceased; (b) yearning, longing, and pining; (c) searching for the deceased; and (d) extreme loneliness. The symptoms of traumatic distress include (a) feeling unfulfilled without the deceased; (b) avoidance of painful reminders of the loss; (c) futility about the future; (d) feeling 
that a part of the self has died; (e) numbness and detachment; $(f)$ shattered world view (regarding trust, security, control); $(g)$ feeling shocked, stunned, and dazed; (h) disbelief about the death; (i) emptiness; (j) taking on symptoms or harmful behaviors of the deceased; and $(k)$ bitterness. (In Neria \& Litz, p. 77)

A clinical study by Eth and Pynoos (1994) revealed that children who were both traumatized and bereaved by witnessing their parents violently murdered had acute posttraumatic stress reactions, which interfered with their ability to successfully grieve. Additionally, these children-survivors tended to regress developmentally, leading to impaired school performance and an inability to trust others and to form meaningful attachments. Similarly, Zvizdic and Butollo (2001) have found that children whose fathers had disappeared in the war in Bosnia suffered from depression as well as posttraumatic stress. Both researchers believe that the elevated levels of symptoms in these children were due to the ambiguity and uncertainty surrounding their father's disappearance. Loss of a loved one who was an integral part of the bereaved individual, social network, and support system produces confusion and pain in the stress response. The grief becomes intensified if the loss occurs by means of violence and if the relationship that is lost is particularly significant in the life the bereaved. Unpredictable loss by malicious violence is one of the most pernicious human experiences, creating the greatest risk for chronic post-loss problems (Neria \& Litz, 2004).

Attachment theory has contributed significantly to the study of loss by virtue of the fact that grief comes from mourning the loss of an attachment relationship. The nature and quality of the attachment relationship is one of the most important determinants of the psychological impact of any type of loss (Parkes, 2002). The study of loss due to malicious violence is hardly found in Indonesia despite the fact that many people have lost their lives as victims of persistent violent conflicts. The families of the victims do not only experience loss by traumatic means, they also bear the additional burden of direct traumatization experiences. This dual nature of loss by traumatic means and traumatization, along with its psychosocial implications have not much been investigated.

The majority of studies exploring the psychological impact of loss and tragedy have primarily focused on negatives consequences such as fear, anger, shame, and guilt (Boerner, Wang \& Cimarolli, 2006). Disruption of daily life activities and relationships and problems with maintaining purpose or meaning of life has also been investigated (e.g., Janoff-Bulman \& Frieze, 1983; Wortman \& Silver, 2004). It is essential to investigate the positive consequences of loss and tragedy to get a better picture of the whole phenomena. Although there is some evidence that stressful life events can produce positive change or growth (e.g., Joseph \& Linley, 2008; Tedeschi \& Calhoun, 2004). Wilson (2006a) even asserts that "it is more important to study the healthy, self-transcendent survivors of trauma than those most dehumanized by it. By understanding the strong, resilient, self-transcendent survivor of extreme life-adversity, we can learn how it is that they found the pathway to healing, recovery, resilience, and the actualization of their innate human potentials" (p.2). The study of testimonial narratives of trauma victims that will be discussed later is done in line with this spirit. Through narratives, we do not only 
look into the negative psychological aftermath of a malicious event, but also how recovery, growth and adaptation have taken place in the lives of these survivors.

The next discussion will focus on how profoundly stressful life events may bring out posttraumatic alterations in the person's identity and personality. John Wilson is one of the trauma experts who has written a great deal about this aspect. Our discussion will heavily draw upon Wilson's work, but to complement his view, other sources will be consulted as well.

Posttraumatic Impact on the Self, Ego Processess, and Identity

Wilson asserts that posttraumatic impacts to the self should be considered as a complex set of factors that alter the integrated structural and functional components of personality processes as a whole. Trauma disrupts the functional quality of ego-processes, producing fluctuating ego-states, identity and selfconfigurations. Wilson's view has been influenced a great deal by psychoanalysis. Freud (1916/1957, quoted in Wilson, 2004) believed that "a person is brought so completely to a stop by a traumatic event which shatters the foundation of his life that he abandons all interest in the present and remains permanently absorbed in mental concentration upon the past" (pp. 33-34). In Beyond the Pleasure Principle (1920/1959), Freud discussed the potential transformative power of trauma, especially to ego processes, as a protection against harm. Similarly, from his work with World War II veterans, Erik Erikson (1968) has developed the concept of identity diffusion and ego identity. From his therapeutic work with these veterans, he has concluded that "Most of our patients had neither been shell-shocked nor beca- me malingerers, but through the exigencies of war lost a sense of personal sameness and historical continuity ... I spoke of a loss of ego-identity" (p. 17). Trauma's impact on ego-processes and defensive systems has, in turn, effects on perception, stress-appraisal processes, attributions of meaning and causality that influence systems of meaning and ideology.

Traumatic events are aversive human experiences that frequently produce undesirable consequences for physical and psychological wellbeing. Traumatic experiences have the power to alter systems of meaning and values. The recovery from trauma often causes individuals to reassess and prioritize their lives and decide what is, and is not, defined as meaningful. Understanding how persons construct systems of meaning in the wake of trauma constitutes an important aspect of the posttraumatic self.

Wilson has identified thirteen symptoms that manifest the traumatic injury to the self-structure, ego processes, personal identity, and personality process. The list of these symptoms is quoted in full:

1. Narcissistic and other personality characteristics that reflect damage to the self-structure associated with trauma.

2. Demoralization, dispiritedness, dysphoria, and existential doubt as to life's meaning.

3. Loss of ego coherence and dissolution of the self-structure.

4. Loss of a sense of sameness and continuity to ego identity or capacity for ego stability.

5. Fragmentation of ego identity and identity disturbance (e.g., identity diffusion). 
6. Shame, self-doubt, loss of self-esteem, guilt, and self-recrimination.

7. Fluctuating ego states; proneness to dissociation and lack of ego mastery.

8. Hopelessness, helplessness, and selfrecrimination; masochistic and selfdestructive tendencies.

9. Suicidality; patterns of self-destructiveness or self-mutilation.

10. Chronic feelings of uncertainty and vulnerability; levels of depression, helplessness, and hopelessness.

11. Existential personal or spiritual angst; dread, despair, and a sense of futility in living.

12. Loss of spirituality, essential vitality, willingness to thrive, religious/cosmic belief systems, and so forth.

13. Misanthropic beliefs, cynicism, and a view of the world as unsafe, dangerous, untrustworthy, and unpredictable. (Wilson, 2004, p. 35)

What constitutes the nature of the posttraumatic self? Trauma affects all dimensions of behavioral and psychological functioning in responding to physical and psychological threats. The effects of traumatic stress can bring about significant alterations in the functional and structural aspects of the brain system and a variety of physical illnesses. (For reviews on this topic, see McNally, 2003; Soesilo, 2012; van der Kolk, McFarlane, \& Weisaeth, 1996; Vasterling \& Brewin, 2005, for example). In order to provide the right answer to the above question, we need to specify first the dimensions of self and personality as has been put forward by Wilson and it then will be clear how each of these dimensions can be adversely impacted by trauma.

\section{The structure and functions of the Self}

The construct of the self is central to internal organizing principles of psychological functioning. It is the self that makes reflective motivational processes possible. As a psychological structure, the self provides a basis for unique identity, self-esteem, and a sense of well-being. It is central to the organization of adaptation and social experience, because as it establishes connections and investments of energy and value in others. Consequently, the self-object (or "the other") matrix of significant others in human development serves as a component of identity formation. Therefore, Wilson argues that "studying the effects of trauma without a conceptually meaningful way to understand traumatic damage to the self is akin to trying to understand degenerative neurological disorders without understanding how the brain functions" (p.33).

Based on the works of Freud, Erikson, Lifton and many other psychologists, Wilson has extracted similarities and consistencies in clinical findings concerning posttraumatic damage to the self. He has come to six core dimensions of the self: (1) coherency, (2) connection, (3) continuity, (4) energy, (5) autonomy, and (6) vitality. Each of these dimensions can be adversely affected by trauma and can result in varying degrees of self-dissolution, disintegration, dissociation, and annihilative effects. These dimensions are also involved in perception, memory, cognition, motivation, and emotional regulation. Trauma can produce damage to the integrated structure of the self or to any of its separate and interconnected dimensions. For instance, child abuse or neglect can lead to ego-fragmentation and a loss of coherence in identity Similarly, abusive violence, torture and political repression can result in a total loss of the self, leading to 
extreme withdrawal, fear, and ongoing intrapsychic brutalization (Wilson, 2006a).

Memory and remembrance lie at the heart of posttraumatic changes in the self. Memory is stored information about the unique and personal aspects of psychological trauma. Remembrance is the process of recalling and reliving different aspects of the trauma experience (Harel, Kahana, \& Wilson, 1993). For people with posttraumatic stress, remembering trauma feels like reliving it (McNally, 2003). In the architectural framework of the posttraumatic self, memories of trauma are, consciously or unconsciously, connected to structural dimensions of the self (i.e., coherence, connection, continuity, autonomy, vitality, energy), ego-processes, and configurations of personal identity (i.e., a sense of continuity vs. discontinuity). Memories of trauma are integral and nuclear components of trauma complexes. Memories of trauma constitute the psychological substrata of all dissociative processes.

\section{Ego processes}

The notion of ego-processes refers to " a complex set of cognitive functions and abilities. In a psychodynamic sense, egoprocesses describe how persons act on the external world in attempting to master experience. The ego, as an agentic quality, seeks to master experience, maintain unity in the self and maximize need gratification" (Wilson, 2006a, p. 15). Ego functions involve security and defensive operations that include protection from threats to the organism from external or internal sources.

The presence of trauma constitutes a clear and significant danger to organismic well-being and activates ego-defensive operations. Ego-defenses primarily have the task of managing fear and anxiety states that could potentially interfere with intellectual and cognitive capacities needed for coping and goal-directed behavior. Depending on the nature, chronicity, and severity of the threat to organismic wellbeing, ego-defenses sustain optimal functioning or eventually become weakened, ineffective, and nonfunctional. When ego loses its defense functionality, other dimensions of the ego may be at risk for failure or inadequate execution of their functional operations (e.g., memory, information processing, abstract thinking, affect regulation).

This condition is consistent with the findings in cognitive psychology. Trauma memo can be triggered in unpredictable manner because the individual cannot consciously identify the trigger for the experience (Fearson \& Mansell, 2001). In fact, cognitive models of PTSD (e.g., Brewin, Dalgleish, \& Joseph, 96; Ehlers \& Clark, 2000) share the central notion that a traumatic experience is both highly salient and incompatible with preexisting models of the self and the world. Furthermore, all these recent cognitive models agree that successful resolution of PTSD involves the integration of info regarding the traumatic experience with existing representational models of self and the world.

Fragmentation in ego-processes can place the self-structure at risk for impaired functioning as well. The loss of egostrength and the capacity to regulate internal systems of the self can result in states of extreme vulnerability, helplessness, and narcissistic injuries. In a similar way, sustaining the constancy of ego functions is critical to the sense of selfsameness and continuity. Clinical research has shown that in the presence of powerful stressors, the ego can lose strength; the entire capacity of the ego-system to perform and integrate its constituent 
functions can degrade and lose vital energy (Erikson, 1968; Wilson \& Drozdek, 2004).

\section{Identity}

The concept of personal identity shares theoretical space with the selfstructure and ego-processes. Wilson states that these personality dimensions are tripartite, interrelated aspects of intrapsychic life. As defined by Erikson (1968), identity imparts a sense of self-sameness and continuity to how the ego master experience, both in time and space.

Personal identity describes the uniqueness of personality, the "stamp of character" and behavioral style across different situations. It is the "stamp" of uniqueness that differentiates persons in terms of their style of ego-mastery and adaptive coping. In this sense, one can meaningfully speak of Eriksonian typologies of identity as defined by two conceptual axes: identity-diffusion vs. identityintegration and self-continuity vs. selfdiscontinuity. Erikson's formulation of personal identity rests on a foundation of stage-specific qualities of ego development. An integrative understanding of psychological trauma requires a unifying theoretical framework by which to examine harm to the self and ego-processes. In Wilson's (2006b) view, Erikson's theory of the epigenesist of identity can help provide us with a useful model by which to analyze different aspects of traumatic impact within stages of ego development. In Erikson's view, the self is a superordinate concept that refers to the integrated structure of identity elements and the ongoing agentic qualities of ego-processes. The aftermath of a traumatic experience can be analyzed by understanding the interrelations of the structure of the self, ego-processes, and identity and the ways in which trauma impacts these processes.

Traumatic Impact on Attachment and Interpersonal Relations

As has been mentioned earlier that trauma can cause disruption of daily life activities and relationships and problems with maintaining purpose or meaning of life. How does trauma affect the nature and quality of interpersonal relationships? Wilson (2004) has listed 13 symptoms that are manifestations of trauma's adverse impact on attachment, intimacy, affiliative behaviors, and interpersonal relations.

1. Alienation: social, emotional, personal, cultural, spiritual.

2. Mistrust, guardedness, secretive behaviors, non-self-disclosure, reticence toward social encounters.

3. Detachment, isolation, withdrawal, estrangement, and feelings of emptiness.

4. Anhedonia: loss of pleasure in living; loss of sensuality, sexuality, feelings, capacity for joy.

5. Object relations deficits; loss of capacity for healthy connectedness to others.

6. Self-destructive or self-defeating interpersonal relationships which are repetitive in nature.

7. Impulsiveness, sudden changes in residence, occupation, or intimate relationships.

8. Impaired sensuality, sexual drive, capacity for sexuality or loss of libidinal energy in general.

9. Inability to relax; discontent with selfcomfort activities and an inability to receive nurturing, affections, or physical touching from others.

10. Unstable and intense interpersonal relationships whose origin is in trau- 
ma experiences.

11. Problems with establishing or maintaining boundaries in relationships based on trauma experiences.

12. Anxiety over abandonment or loss of loved ones, which is either conscious or unconscious in nature and based in traumatic experiences.

13. Repetitive self-defeating interpersonal relationships which reflect unmetabolized patterns of attachment behavior from abusive developmental experiences. (Wilson, 2004, pp. 36-37)

Wilson states that all these symptoms were not present before the trauma. All the manifestations of these symptoms show us how complex and multidimensional are trauma and its aftermath.

\section{Coping}

Coping has to do with the way people manage life conditions that are stressful. To some extent, stress and coping could be said to be reciprocals of each other. When coping is ineffective, the level of stress is high; however, when coping is effective, the level of stress is apt to be low (Lazarus, 1999). The basic idea of coping is certainly not new, as is evident in the psychoanalytic concept of ego defense. The concept of coping was developed largely out of the work of Lazarus. One of Lazarus's main contributions to research and thought on coping is his formulation of coping as process. Lazarus and Folkman (1994) offer their process definition of coping as follows: "We define coping as constantly changing cognitive and behavioral efforts to manage specific external and/or internal demands that are appraised as taxing or exceeding the resources of the person" (p.141). So the process formulation of coping is justified because under a stressful life situation the person wants to change and coping must reflect the sensitivity to changing relational demands.

Lazarus (1999) asserts that no universally effective or ineffective coping strategy exists. "Coping must be measured separately from its outcomes, so that the effectiveness of each coping strategy can be properly evaluated. Efficacy depends on the type of person, the type of threat, the stage of the stressful encounter, and the outcome modality-that is, subjective well-being, social functioning, or somatic health. Because the focus is on flux or change over time and diverse life conditions, a process formulation is also inherently contextual" (p. 111).

In this perspective, we have to look at the social role context of coping that is less discussed by Lazarus. It is important to consider this because the majority of traumatized victims in Indonesia are those who can be categorized as belonging to a minority group.

Traumatized people develop their own peculiar defenses to cope with intrusive recollections and increased physiological arousal. Their choice of defenses is influenced by developmental stage, temperamental and contextual (social, political, cultural) factors. Hence, the diagnosis of PTSD alone never captures the totality of people's suffering and the spectrum of adaptations that they engage in.

Emotion-focused coping has indeed been shown to be more effective than problem-focused coping, yet both are needed to successfully deal w a loss (Stroebe \& Schut, 1999). Coping style may moderate the effect of gender on grief, as men generally tend to use problemfocused coping, while women typically use both forms of coping to deal $\mathrm{w}$ loss (Stroebe \& Schut, 2001). However, concerning the relationship between coping 
and social roles, Hobfoll, Schwarzer, and Chon (1998) have argued that women may select emotion-focused rather than problem-focused coping because it is a better match to their typical situational demands. Similarly, much of problemfocused coping is dictated by social roles.

One criticism of coping research put forth by Hobfoll et al., is that coping research has concentrated more on quantity rather than on quality of coping. Almost exclusive attention has been paid to the degree people enact problem solving efforts, emotional channels, or social and family support. According to Hobfol, this kind of study has little to say about how well people actually cope. Effectiveness of coping as a resource therefore should deserve greater attention.

Lazarus (1999) himself would agree with this suggestion when he states that research on the coping process requires an intraindividual research design, studied in different contexts and at different times. Comparisons between individuals then must also be made to observe how much change and stability is found in what is happening within any individual. This opens the window for the study of narratives of the people who have gone through malicious and dreadful life events, such as political suppression and torture and violent communal conflicts. In Pennerbaker's (1989) view, writing is a way to enhance coping as a resource and to encourage alternate interpretations of events. He also found that those undergoing stressful life events and wrote about their experiences do not experience negative health consequences of those who do not record their experience.

Using the narratives as our data we must sample reactions to demands even during periods when they are being handled smoothly and without great evi- dence of emotional distress. This suggests that coping should not be exclusively defined in terms of the resolution of the stress. Chronic sources of stress, as in longterm ailments, such as heart disease or arthritis, must often be lived with and managed rather than resolved. Thus, coping may not be capable of terminating the stress, but the person can often manage it, which includes tolerating or accepting the stress and distress (Lazarus, 1999).

Lazarus (1999) discussed the work by Cignac and Gotlieb (1997) who studied the stress experienced by caregivers who cared for a demented relative, such as Alzheimer's patients. The coping strategies found in this study are presented here because the list is much broader, and therefore, more beneficial, than the category of problem-focused and emotionfocused coping as presented by Lazarus (See Table 1).

Additionally, Cignac and Gotlieb also examined appraisal types and their coping efficacy (See Table 2). This information is rarely found in articles published in Indonesian psychological journals and will be more helpful for us when we study narratives which will be discussed later.

Lazarus's (e.g. Lazarus 1999) more recent thought has shifted toward the adoption of narrative perspective in his approach to the study of stress. He defines emotion narrative as "a dramatic plot or story that describes the provocation of the emotion and its background, which helps define what made some action, or lack of action when it is desired, provocative, and how it progressed and turned out. The drama begins with the provoking action and proceeds through the continuing transaction - usually interpersonal. The provocation is best viewed as the figure in a figure-ground relationship" (p.205, italics original) 
Table 1

Definitions of Classes of Coping

Making meaning

Acceptance

Positive framing

Wishful thinking

Avoidance/escape

Vigilance

Emotional repression

Emotional inhibition

Optimistic future expectancies

Pessimistic future expectancies

Humor

Help-seeking

Verbal symptom management

Behavioral symptom management
The patient's behavior is attributable to the disease from which the patient suffers and is not a result of the type of a person he/she is

Acceptance of the patient's disease/behavior and/or the necessity of continued involvement in caregiving

Focus on positive aspects and/or the negative Repercussions of caregiving minimalized

The wish that the course of the disease and/or caregiving responsibilities would change

Physically withdrawing from caregiving for short periods of time and/or cognitively avoiding thinking about caregiving responsibilities

Continuously watchful of the patient and/or are mentally preoccupied with thoughts about the patient

Coping by expressing emotions openly

Coping by inhibiting emotions and/or admonishing self not to express emotions

Optimistic or hopeful regarding ability to manage caregiving responsibilities in the future

Pessimistic regarding ability to manage caregiving responsibilities in the future and/or fear of suffering a similar fate as the patient

Teasing and or joking with the patient when patient exhibiting dementia symptoms

Seeking practical and/or emotional support from others

Managing patient's behavior with a range of verbal strategies such as explanations, changing subject, reassuring and calming patient, making requests, and instructing patient

Managing patient's behavior with a range of behavioral strategies such as assisting patient with tasks, interrupting behavior with distracting activities, rearranging environment, and taking over tasks and decision

Adapted from Cignac \& Gotlieb (1997), pp. 249-251. 
Table 2

Types of Appraisals of Coping Efficacy

\begin{tabular}{|c|c|}
\hline Appraisal type & Definition and examples \\
\hline Efficacious coping outcomes & $\begin{array}{l}\text { Appraisals of successful coping outcomes; e.g., "I found } \\
\text { this [letting the behavior play out] is the best thing." "I've } \\
\text { tried everything but [changing the subject] seems to } \\
\text { work." }\end{array}$ \\
\hline $\begin{array}{l}\text { Nonefficacious coping } \\
\text { Outcomes }\end{array}$ & $\begin{array}{l}\text { Appraisals of unsuccessful coping outcomes; e.g., } \\
\text { "Overnight she'll forget what we talked about and then it } \\
\text { might start over again." "But it don't do no good. Tell her } \\
\text { to shut up, you might as well try throwing gas on a } \\
\text { fire. Just puts her in gear." }\end{array}$ \\
\hline No coping options & $\begin{array}{l}\text { Appraisals that nothing further can be done to manage the } \\
\text { stressor's demands; e.g.", She has the problem and there } \\
\text { isn't anything I can do to change it." "I just give up." }\end{array}$ \\
\hline Control appraisals & $\begin{array}{l}\text { Appraisals that respondents are exercising influence over } \\
\text { the stress and their emotions; e.g., There's quite a few } \\
\text { things that I do to, uh, control myself and that there." "I'm } \\
\text { fortunate enough to be able to control any upset feelings." }\end{array}$ \\
\hline No control appraisals & $\begin{array}{l}\text { Appraisals that respondents are unable to influence the } \\
\text { stressor or control their emotions; e.g., It's a situation that } \\
\text { I can't control and I think that's probably what frustrates } \\
\text { me. Most situations I can control!" "Most of the time, it's } \\
\text { anger, very difficult to keep it in." }\end{array}$ \\
\hline Less stressor reactivity & $\begin{array}{l}\text { Appraisals that the respondent is able to tolerate the } \\
\text { stressor; e.g., "I think I'm ... probably sensitive to a } \\
\text { point, but now I'm so used to it that it's just water off a } \\
\text { duck's back." }\end{array}$ \\
\hline More stressor reactivity & $\begin{array}{l}\text { Appraisals that the respondent is unable to tolerate the } \\
\text { stressor; e.g., "I get more upset than I did. You think } \\
\text { you'd get used to it, but I'm never get used to that. }\end{array}$ \\
\hline Depletion of energy & $\begin{array}{l}\text { Appraisals of diminished energy; e.g., "I didn't know } \\
\text { what it was at first but ... trying to cope with it all, it's } \\
\text { tiring me out." }\end{array}$ \\
\hline Improved ability to cope & $\begin{array}{l}\text { Appraisals of improvements in coping' e.g., "I cope much } \\
\text { better } \\
\text { Now. In the past, I would lose my own temper. I don't do } \\
\text { that anymore." }\end{array}$ \\
\hline Coping self-criticism & $\begin{array}{l}\text { Appraisals of one's shortcomings in coping; e.g., "You } \\
\text { know you are thinking maybe you've done something } \\
\text { wrong. I should be more sympathetic and then maybe the } \\
\text { rest of the day would have been better." }\end{array}$ \\
\hline Strategic planning & $\begin{array}{l}\text { Appraisals of the costs and benefits entailed in different } \\
\text { coping efforts; e.g., "I remind myself to watch what I do } \\
\text { next time in a similar circumstance.... To not go into a lot } \\
\text { of detail with my notes and that I talk to myself to } \\
\text { remember." }\end{array}$ \\
\hline
\end{tabular}

Source: Cignanc \& Gotlieb (1997), pp. 250-251. 
Lazarus's (e.g. Lazarus 1999) more recent thought has shifted toward the adoption of narrative perspective in his approach to the study of stress. He defines emotion narrative as "a dramatic plot or story that describes the provocation of the emotion and its background, which helps define what made some action, or lack of action when it is desired, provocative, and how it progressed and turned out. The drama begins with the provoking action and proceeds through the continuing transaction - usually interpersonal. The provocation is best viewed as the figure in a figure-ground relationship" (p.205, italics original).

\section{Narrative Strategies}

People are motivated to make sense of what happens to them and find meaning from their life experience, which is typically achieved through creating narratives (Baumeister \& Newman, 1994). In the creative process of narrating, an initially disorganized or less structured mental representation is made more integrated and coherent, and this explains the efficacy of expressive writing (Boals, Banks, \& Hathaway, 2011).Use of cognitive words in writing has been used by Pennebaker and Francis (1996) to indicate the extent to which the writer has achieved a coherent narrative. The increased amount of cognitive processing is associated with the writer's effort to fit their narrative for the new event into their existing schema.

Traumatic events can shatter one's view of the self as a normal human being and of the world as safe and benevolent. However, people are motivated to engage in a search for meaning and purpose to life and restore self-esteem. The restoration of meaning and wholeness to self following trauma is in itself a high level process of functioning. This search for meaning, or often called meaning making, involves " coming to see or understand the situation in a different way and reviewing and reforming one's beliefs and goals in order to regain consistency among them" (Park \& Ai, p. 393). Meaning making is viewed as a core feature of the coping process and is generally related to positive outcomes (Bergner,2009; Boals, Banks, \& Hathaway, 2011; Wilson, 2004).

Based on their review of the socialpsychological literature on the nature of meaning, Baumeister and Vohs (2002) have come to four basic patterns involved in the process of creating systems of meaning. These four patterns are: (1) a sense of individual purpose; (2) values which are hierarchically organized and generate positive outcomes; (3) a sense of self-efficacy in the pursuit of purpose; and (4) a sense of self-worth in carrying out one's goals and responsibilities in life. Baumeister and Vohs state that the capacity to create systems of personal meaning is linked to appraisal processes: This reappraisal [process] often involves finding some positive aspect in a negative event. The transformation process from adversity to prosperity has been referred to as the benefit-finding aspect of meaning-making ... A second aspect of meaning-making involves looking for attributes in an effort to understand the events. This aspect has been referred to as the sense-making function of meaning-making . . . Meaningmaking also has been defined as the search for significance" (p. 613).

The posttraumatic self faces the challenge of finding meaning in traumatic experiences and personal suffering. Feelings of self-worth and the basis of appraising self-efficacy may change in purpose, value, and priority. This process of change from the pretrauma organi- 
zation of values, beliefs and ideology is, in itself, a transformational process indigenous to survivorship. Viewed in this way, "meaning-making" and personal identity are two sides of a coin. There is no inner sense of identity without a system of meaning to guide value choices and personal goals (Wilson, 2004).

Life story or narrative weaves together a set of significant remembered episodes into a coherent whole that guides our understanding of ourselves and our goals and actions. These most important memories are memories that define self (Singer \& Salovey, 1993). Self-defining memories are vivid, emotionally intense, repetitively recalled, linked to similar experiences, and organized around an ongoing concern or unresolved conflict within the individual personality These self-defining memories serve the function within the individual's narrative of capturing critical recurring themes and affective scripts that help to communicate to self and to others what matters most in one's life.

All cultures (and families are small cultures of their own) have implicit cultural life scripts that define preferable or acceptable ways to be and act. The narratives one generates to answer the question of identity are wrought from the cultural and communal scripts that both speaker/writer and listener have in mind when narrating events. These scripts provide the framework for narrative material (Baddeley \& Singer, 2010). The intimate details of one's narrative of loss and suffering suggest a complex process of adaptation to a changed reality of world, a process that is simultaneously personal and cultural. The memories narratives may convey the distinct roles of "hero", "victim", "scapegoat", "lost child", or "perpetrator."

The intimate details of people's stories of loss suggest a complex process of adaptation to a changed reality, a process that is at the same time immensely personal, intricately relational, and inevitably cultural. The themes on which people draw to attribute significance to their lives will reflect political and belief systems that inform their personal attempts at meaning making.

\section{Conclusion}

Violent events have become an almost daily scene in our lives. Many people have to bear a permanent impact left by the scars of trauma. Study of socialpsychological trauma has confronted us with the best and worst nature of human being. What constitutes trauma and how trauma affects the life of the victim has been discussed in this paper. As a fenomenon related to stress, it would be beneficial if the impact of stress takes into account of the self, which the self itself is multifactorial or multifaceted concept. Discussion on coping needs to be broader than what has been proposed by Lazarus. This broader perspective will be more beneficial when we especially intend to investigate narrative or lifestory as an attempt by the individual to undertand what has happened to them and to make sense of their altered life. This struggle and process may easily be come to surface in a narrative. 


\section{References}

American Psychiatric Association. (2000). Diagnostic and statistical manual of mental disorders (4th ed., text rev.). Washington, DC: American Psychiatric Association.

Baddeley, J., \& Singer, J. A. (2010). A loss in the family: Silence, memory, and narrative identity after bereavement. Memory, 18, 198-207.

Baumeister, R. F., \& Vohs, K. D. (2002). The pursuit of meaningfulness in life. In C. R. Synder \& S. Lopez (Eds.), Handbook of positive psychology (pp. 608-632). New York: Oxford University Press

Bergner, R. M. (2009). Trauma, exposure, and world reconstruction. American Journal of Psychotherapy, 63, 267-282.

Boals, A., Rubin, D.C., \& Klein, K. (2008). Memory and coping with stress: The relationship between cognitive-emotional distinctiveness, memory valence, and distress. Memory, 16, 637-657.

Boals, A., Banks, J. B., Hathaway, L. M., \& Schuettler, D. (2011). Coping with stressful events: Use of cognitive words in stressful narratives and the meaning-making process. Journal of Social and Clinical Psychology, 4, 378403

Boerner, K., Wang, S. W., \& Cimarolli, V. R. (2006). The impact of functional loss: Nature and implications of life changes. Journal of Loss and Trauma, 11, 265-287.

Brewin, C.r., Dalgleish, T., \& Jospeh, S. (1996). A dual representation theory of posttraumatic stress disorder. Psychological Review, 103, 670-686.

Caruth, C. (1995). Trauma and memory. Baltimore: Johns Hopkins University Press
Cignac, M. A. M., \& Gottlieb, B. H. (1997). Changes in coping with chronic stress: The role of caregivers' appraisals of coping efficacy. In B. H. Gottlieb (Ed.), Coping with chronic stress (pp. 245-267). New York: Plenum

Conrad, C. D. (Ed.)(2011), The handbook of stress: Neuropsychological effects on the brain. Malden, MA: Blackwell.

Dennis, M. R. (2008). The grief account: Dimensions of a contemporary bereavement genre. Death Studies, 32, 801-836.

Drozdek, B., Turkovic, S., \& Wilson, J. P. (2006). Posttraumatic shame and guilt: Culture and the posttraumatic self. In J.P. Wilson (Ed.), The posttraumatic self: Restoring meaning and wholeness to personality (pp. 333-368). New York: Routledge.

Ehlers, A., \& Clark, D. M. (2000). A cognitive model of posttraumatic stress disorder. Behavior Research and Therapy, $38,319-345$.

Eid, J., Johnsen, B.H., \& Saus, E-R. (2005). Trauma narratives and emotional processing. Scandinavian Journal of Psychology, 46, 503-510.

Eth, S., \& Pynoos, R. S. (1994). Children who witness the homicide of a parent. Psychiatry, 57, 287-306.

Fearson, R. M., \& Mansell, W. (2001). Cognitive perspectives on unresolved loss: Insights from the study of PTSD. Bulletin of the Menninger Clinic, 65, 380396.

Freud, S. (1916/1957). The introductory lecture on psychoanalysis. In J.W. Strachey (Ed., and Trans.), The standard edition of the complete psychological work of Sigmund Freud. New York: Norton.

Freud, S. (1920/1959). Beyond the pleasure principle. In J.W. Strachey (Ed., and 
Trans.), The standard edition of the complete psychological work of Sigmund Freud. New York: Norton.

Green, B. L. (2000). Traumatic loss: Conceptual and empirical links between trauma and bereavement. Journal of Personal and Interpersonal Loss, 5, 1-17.

Green, B. L., Krupnick, J. L., Stockton, P., Goodman, L., Corcoran, C., \& Petty, R. (2001). Psychological outcomes associated with traumatic loss in a sample of young women. American Behavioral Scientist, 44, 817-837.

Hobfoll, S. E., Schwarzer, R., \& Chon, K. K. (1998). Disentangling the stress labyrinth: Interpreting the meaning of the term stress as it is studied in health context. Anxiety, Stress and Coping, 11, 181-212.

Howarth, R. A. (2011). Concepts and controversies in grief and loss. Journal of Mental health Counseling, 33, 4-10.

Janoff-Bulman, R., \& Frieze, I. H. (1983). A theoretical perspective for understanding reactions to victimization. Journal of Social Issues, 39, 1-17.

Joseph, S., \& Linley, P. A. (Eds.)(2008). Trauma, recovery, and growth. Hoboken, NJ: John Wiley \& Sons.

Lazarus, R. S. (1999). Stress and emotion: A new synthesis. New York: Springer.

Lazarus, R. S., \& Folkman, S. (1984). Stress, appraisal, and coping. New York: Springer.

Marin, M. F., \& Lupien, S. J. (2011). Stress and glucocorticoid effects on learning and memory. In C.D. Conrad (Ed.), The handbook of stress: Neuropsychological effects on the brain (pp. 248-265). Malden, MA: Blackwell.

McNally, R. J. (2003). Remembering trauma. Cambridge, MA: Belknap Press.
Neria, Y., \& Litz, B.T. (2004). Bereavement by traumatic means: The complex synergy of trauma and grief. Journal of Loss and Trauma, 9, 73-87.

Park, C. L., \& Ai, A. L. (2006). Meaning making and growth: New directions for research on survivors of trauma. Journal of Loss and Trauma, 11, 389-407.

Parkes, C. M. (2002). Grief: Lessons from the past, visions for the future. Death Studies, 26, 367-385.

Pennenbaker, J. W.(1989) Confession, inhibition and disease. Advancesin Experimental Social Psychology, 22, 211-244.

Pennebaker, J. W., \& Francis, M. E. (1996). Cognitive, emotional, and language processes in disclosure. Cognition and Emotion, 10, 601-626.

Singer, J. A., \& Salovey, P. (1993). The remembered self. New York: Free Press.

Soesilo, A. (2012). Apakah stress traumatis mengganggu otak? Efek neuropsikologis stress atas otak. Prosiding Seminar dan Serial Diskusi Ilmiah Psikologi Kesehatan Dalam Rangka Dies Natalies ke 28: “Otak, Proses Kognitif, dan Perilaku Sehat" (pp. 89-125). Unika Soegijopranoto, Semarang.

Stroebe, M., \& Schut, H. (1999). The dual process model of coping with bereavement: Rationale and description. Death Studies, 23, 197-224

Tedeschi, R. G., \& Calhoun, L. G. (2004). Posttraumatic growth: Conceptual foundations and empirical evidence. Psychological Inquiry, 15, 1-18

Van der Kolk, B.A., \& McFarlane, A.C. (1996). The black hole of trauma. In B.A. van der Kolk, A.C. McFarlane, \& L. Weisaeth (Eds.), Traumatic stress: The effects of overwhelming experience on mind, body, and society (pp. 3-23). New York: Guilford. 
Van der Kolk, B. A., \& McFarlane, A. C., \& Weisaeth, L. (Eds.)(1996). Traumatic stress: The effects of overwhelming experience on mind, body, and society. New York: Guilford.

Vasterling, J. J., \& Brewin, C. R. (Eds.)(2005). Neuropsychology of PTSD: Biological, cognitive, and clinical perspectives. New York: Guilford.

Wilson, J. P. (2004). PTSD and complex PTSD: Symptoms, syndromes, and diagnoses. In J.P. Wilson \& T.K. Keane (Eds.), Assessing psychological trauma and PTSD (2nd ed.). New York: Guilford.

Wilson, J. P. (2006a). The Posttraumatic self. In J.P. Wilson (Ed.), The posttraumatic self: Restoring meaning and wholeness to personality (pp. 9-68). New York: Routledge.
Wilson, J. P. (2006b). Trauma and the epigenesis of identity. In J.P. Wilson (Ed.), The posttraumatic self: Restoring meaning and wholeness to personality (pp. 69-116). New York: Routledge.

Wilson, J. P. (2006c). Trauma and alterations in normal personality. In J.P. Wilson (Ed.), The posttraumatic self: Restoring meaning and wholeness to personality (pp.255-294). New York: Routledge.

Wortman, C. B. (2004). Commentaries on posttraumatic growth: Progress and problems. Psychological Inquiry, 15, 8190.

Zvizdic, S., \& Butollo, W. (2001).Warrelated loss of one's father and persistent depressive reactions in early adolescents. European Psychologist, 6, 204-214. 